\title{
REINFORCEMENT OF Maja Labo Dahu (SHAME AND FEAR) ATTITUDE IN PRACTICING PANCASILA VALUE THROUGH THE LEARNING OF PANCASILA AND CIVIC EDUCATION IN State Madrasah Tsanawiyah (MTSN) 1 BIMA CITY
}

\author{
Bambang Irawan, Eny Kusdarini
}

This type of research is a descriptive research by the qualitative approach about the reinforcement of maja labo dahu attitude in practicing Pancasila value through the learning of Pancasila and civic education in State Madrasah Tsanawiyah (MTsN) 1 Bima City. The technique of determining the research subject that used purposive sampling with the source of data is: 1) teacher of Pancasila and civic education, 2) student representatives, 3) curriculum representative, 4) coach of extracurricular activity, 5) principal and, 6) students.

The data collection is conducted by observation, documentation and interview. The test validity is conducted by triangulation technique. The data analysis is made by the technique of qualitative descriptive analysis. The research founding indicated that: first, the reinforcement of maja labo dahu attitude in practicing Pancasila values in MTsN 1 Bima City can be done by several ways, such as: a) verbally, by giving the understanding the meaning about the important of maja labo dahu philosophy toward students, b) exemplary, teacher can show a positive behaviour and attitude, for instance: courtesy, honesty, discipline, and appearance that can be imitated by students, and c) habituation of religious attitudes, politeness, mutual respect and tolerance. Second, the supporting factor of reinforcement of maja labo dahu attitude in practicing Pancasila values through the learning of Pancasila and civic education in MTsN 1 Bima City, including: a) a competent teacher, b) facility, c) curriculum, d) extracurricular activity, e) school culture, $f$ ) parents and society, $g$ ) the involvement of all the teacher and school staff. Meanwhile, the obstacle factor, including: a) the curriculum content has not listed explicitly the philosophy of maja labo dahu, b) the large school environment, c) school environment, family and society do not support each other. However, the solution of the reinforcement of maja labo dahu attitude toward students is not only the Pancasila and civic education teacher's responsibility, but it needs the involvement of all school sides to conduct supervision, assistance, family environment, community and government. Third, the form of practicing the values of Pancasila in MTsN I Bima city, including: first principle, divine value (learning to read Al-Qur'an, hadith, praying in congregation, lecturing and reading yasin); the second principle, the value of humanity (tolerance, help, kinship, and mutual respect); the third principle, the value of unity (raising the red and white flag, commemorating the Proclamation Day of August 17, reforestation, and loving local culture). The fourth principle, the value of populism (deliberation and consensus, the selection of class chairmen, student council chairmen, scout leaders and harvest discussions). And the fifth principle, the value of justice (sense of brotherhood, solidarity, tolerance and help)

Keywords: Maja labo Dahu, Practicing Pancasila value, Pancasila and Civic Education

Copyright (C) 2021, Bambang Irawan, Eny Kusdarini.

This is an open access article under the CC BY license (http://creativecommons.org/licenses/by/4.0).

\section{Introduction}

Civic education and religious education is a lesson, closely related to the ones that shape the moral and character of generations. Along with Kerr's opinion [1] that civic education can be interpreted in depth that aims to provide a good and responsible young generation as citizens. A representative as a good citizen is having a noble, creative, participatory, democratic, law-abiding and governmental morality. Furthermore Budimansyah [2] argues that civic education is one of the subjects that have a function to prepare the generation of the nation that has an insight into the love of the country. Furthermore, Budimansyah explained other functions, civic education subjects aim to realize a competent generation with the following characteristics:

1) Critical thinking, and rational to respond the national issues, such as poverty, injustice and crime,

2) responsible in building a better social life of society,

3) Forming a strong character of students to practice the values of Pancasila,
4) Having a sense of nationality and care about international world.

Ubaedillah and Abdul Rozak [3] emphasized that civic education has an important role to play in making Indonesian citizens intelligent, dignified and active in life of the nation and state. Citizens that have knowledge and morality can certainly control themselves from criminal acts and can practice the values of Pancasila properly and correctly. According to the master design of character development of the Indonesian nation from the problem mentioned, the uncertainty of identity and character of the nation is indicated that cause;(1) the lack of awareness to inspirit the values of Pancasila as the philosophy of life and ideology of the Nation of Indonesia, (2) The limitations of policy devices to realize the values of Pancasila and the government should fully support realization of the nation character that reflects the values of Pancasila, (3) The fading of ethical values in the life of the nation and state, (4) the threat of nation disintegration, and (5) the lack of independence of the Indonesian nation [4]. 


\section{Literature review}

The educational environment should be a place for academic people that have knowledge, noble morality, manners, mutual respect and care for the surrounding environment. However, it is always tarnished by criminal acts in the form of inter-student abuse, drug abuse, teacher fighting, undisciplined behaviour, sexual harassment and decreased learning achievement. Those problems often occur so that it can tarnish educational institutions. Those problems that condition the educational environment in the Bima regency are not far from problems, such as ones that occur in the educational environment throughout Indonesia. The condition shows the collapse of generational morality therefore it causes a number of problems about juvenile delinquency, involved in a number of crimes, lazy, decreased learning achievement and so on.

Iskarim, M [5] revealed that in the midst of the nation's moral decadence', there must be a figure that can provide a role model that can invite and teach, which is appropriate with the values of religion, customs and culture of the nation. Because the role model of the teacher is quite influential for the formation of the character of the students. Since the students can imitate directly according to what they see. Therefore, the appearance of teachers and their speech will always be the centre of attention for students. Moreover, in the family environment, positive habits, carried out by the father and mother, support for the development of student character. Morawska et al [6] explained that the pattern of family parenting by interaction practice between parents and children, based on a positive treatment model has an effect on the development of their children's potential and character. The involvement of the role of the family in the effort of teaching, educating and guiding can help the school in realizing the character of students. Although in general in some previous studies, Oberle et al [7] found that for positive development during early adolescence, the support from peer groups and other communities is important. Furthermore, community and religious leaders have an important role to help in educating students so that students have a national character, which is appropriate with maja labo dahu attitude. The three forms of educational environment are mutually influential in shaping the attitudes and character of students, based on local wisdom.

Basically, Bimanese people have the politeness manners, mutual cooperation, care about the environment, peace-loving and religious. But along with the development of the era, the positive habits, carried out by the community, containing cultural values of shame and fear (philosophy of life) by Bimanese people, have begun to be abandoned. The problem is a result of globalization and influenced by several factors, such as: family that have not given an understanding of the importance of maja labo dahu as the philosophy of Bimanese's life in life, the lack of government socialization, the lack of educational role to provide planting and reinforcement of local wisdom value and modern life tends to influence the mindset of generations to be indifferent in studying their own culture.

A number of problems, often occurring in Bimanese society and students, are social conflict, sexual harassment, motorcycle theft, murder, prostitution, fraud, motorcycle racing, alcohol, gambling, inter-student brawls, early marriage, and low learning achievement. The problem is inseparable from the shift in cultural values of Bimanese people, upholding the philosophy of maja labo dahu (shame and fear). In fact, Bimanese people are known as a society that is still thick with the values of tolerance, solidarity, mutual cooperation and high religious values. But now it has begun to shift with the changing times. Therefore, the importance of the reinforcement of Maja Labo Dahu (shame and fear) attitude in practicing the values of Pancasila through the learning of Pancasila and Civic education in MTsN I Bima City. So that students as a young generation have an understanding of cultural values, formed a character that reflects the philosophy of maja labo dahu (shame and fear) such as, religious, honest, discipline, responsibility, tolerance and spirit of learning, and by having an attitude of maja labo dahu (shame and fear), students will be encouraged in practicing the values of Pancasila in everyday life.

\section{The aim and objectives of the study}

The loss of Maja Labo Dahu's attitude towards students of MTsN I in Bima City will have an impact on decreasing learning achievement, indiscipline, dishonesty, cheating, truancy and lack of awareness in practicing the values of Pancasila. Considering the above background, the aim of this study was to strengthen Maja Labo Dahu's attitude (fear and shame) to practice the values of Pancasila in MTsN 1 Kota Bima.

To accomplish the aim, the following tasks have been set:

a) To know the Supporting Factor of The Reinforcement of Maja Labo Dahu (Shame and Fear) Attitude

b) To know the Obstacle Factor of the reinforcement of maja labo dahu (Shame and Fear) Attitude

c) To know the Practicing model of Pancasila Value in the Environment of MTsN 1 Bima City

\section{Research method}

This type of research is a descriptive research with the qualitative approach. Nawawi. H [8] explains that descriptive research is a type of research that its problem-solving procedures are investigated by describing the state of the subject or object of research (a person, institution, and society) in the form of social activity, attitude, belief and perception, based on fact that include the interpretation of data and data analysis, conducted by the researcher. Then the approach, used in this research, is the qualitative approach. According to Moleong. L [9] the qualitative research method is a research that aims to understand the phenomenon, experienced by research subjects, for example, behaviour, perception, motivation and others holistically and by describing in the form of words and sentences against research objects, not by numbers [10].

\section{Result. The Reinforcement of Maja Labo Dahu (Shame and Fear) Attitude}

Reinforcement is one of the teacher's ways to educate students both in the classroom and outside the classroom. The reinforcement of maja labo dahu (shame and fear) attitude in practicing the values of Pancasila in MTsN I Bima city can be done in several ways, such as 
verbally, nudity and habituation. As explained by madam Nuro'in Wahyu Purnama, a Pancasila and Civic Education teacher is described as follows.

"The reinforcement of maja labo dahu can be done by providing understanding (orally) the meaning. Then, the teacher can show an attitude and exemplary that can reflect the maja labo dahu attitude, such as politeness, honesty, discipline, responsibility, and neatness, so that students can imitate it. And then get used to bringing greetings, praying before and after learning, having a sense of clean and mutual cooperative. This case, indirectly can cultivate maja labo dahu attitude towards students. Maja labo dahu is important for students as a moral basis to limit themselves from disrepute and can also provide encouragement for students to achieve development”. (NWP/G.PPKn/20/07/20).

NWP emphasizes that the reinforcement of maja labo dahu (shame and fear) attitude towards students can be done by verbally, exemplary and habituation. This can be done by a Pancasila and Civic Education teacher as well as for all teachers in MTsN I Bima City. Furthermore, madam Nurhasannah as a student representative explained that:

First, applying a culture of discipline can affect the attitude of maja labo dahu (shame and fear) in students due to the habits that can affect the awareness of the students. For instance, the discipline of coming on time is important because they can get the subject matter, delivered by the teacher. Second, sanctioning students when they make a mistake can cultivate an attitude of maja labo dahu (shame and fear) towards the student because of the fear of being expelled at school and can tarnish the good name of parents. Third, giving attention toward both troubled and not troubled students can reinforce the sense of maja labo dahu (fear and shame) because students, who have such attitudes, will be careful to take an action outside of the existing rules (N/WS/14/07/20).

The statement from $\mathrm{N}$ can be widely described that maja labo dahu attitude can grow through enforcing school discipline. By giving sanctions if finding a student that break the role to raise awareness in complying with school rules. Because if students do not have an attitude of maja labo dahu (shame and fear), they will tend to do deviant behaviour such as skipping, cheating, coming late, not wearing complete school attributes, littering, late for school, and like to disturb friends

\subsection{Supporting Factor of The Reinforcement} of Maja Labo Dahu (Shame and Fear) Attitude

There are several supporting factors to facilitate the reinforcement of Maja labo dahu (shame and fear) attitude towards students in MTsN 1 Bima city, based on the findings in the field as follows:

1) pedagogical competency of a teacher, including academic skills with material mastery, randomness and ability to master the classroom,

2) facility is a means, which is quite helpful for the success to form cognitive, affective and psychomotor as- pects of children, especially CCTV one of the tools, needed to control, so that it forms the character of children,

3) school culture.

5.2. Obstacle Factor of the reinforcement of maja labo dahu (Shame and Fear) Attitude

There are obstacle factors in the reinforcement of maja labo dahu (shame and fear) attitude towards students in MTsN 1 Bima city, based on the findings in the field as follows:

1) the material content about maja labo dahu philosophy (shame and fear) has not been included in the Pancasila and Civic education lesson material,

2) the school environment is wide enough that it will be difficult for picket teachers to control student activities,

3) CCTV installation is still limited,

4) the lack of support from the family and community, so that the cultivating character in school is not sustainable.

5.3. Practicing model of Pancasila Value in the Environment of MTsN 1 Bima City

A practicing model of the Pancasila value, conducted by students in MTsN 1 Bima city, is based on the findings, such as: 1) divine principle, reflected in students' habit in carrying out the Islamic teaching (reading the Qur'an, memorizing hadith, and praying sunnah and obligatory in congregation), 2) the principles of humanity, including tolerance, care, solidarity and mutual assistance, 3) the principle of unity, in the form of mutual trust, tolerance and raising the red and white flag, 4) populist principle, taking the participation in the election of the chairman of the student organization, 5) the principle of justice, looking at each other in an equal way without bullying.

\section{Discussion}

Local wisdom in anthropological terms is also known as local genius. Local genius was first discovered by a researcher, named Quaritch Wales. Local wisdom can be understood as the wisdom, knowledge, and intelligence of the local community, so that it becomes a local point of view that can influence various knowledge and activities, which is used to face all problems [11]. While Mungmachon [12] understands that local wisdom can be interpreted as a system of knowledge, practice, and representative of community habits that are preserved from generation to generation with the environment.

Furthermore, Alfian [13] explained that local wisdom is used as a view of life, knowledge and strategy in the form of local community activities to achieve life goals. Since local wisdom is part of the community's culture that needs to be preserved because it contains the values, normative and practical in everyday life. Maja labo dahu (shame and fear) is one of the values of local wisdom of Bimanese people, derived from religious values, culture, history, and customs. Maja labo dahu philosophy (shame and fear) is a teaching about ethics and aesthetics in Bimanse people's lives, which is upheld.

The reinforcement of maja labo dahu (shame and fear) attitude is an effort, made by an educator by social- 
izing students to understand, recognize and preserve maja labo dahu (shame and fear) as a form of local wisdom value. Maja labo dahu (shame and fear) is the basic attitude that every individual has as a form of obedience to all the rules of life. Students having maja labo dahu (shame and fear) attitude will certainly have the awareness to control their mind, heart and behaviour into prohibited actions. Maja labo dahu (shame and fear) values remain based on cultural values, philosophical values, customs and Islamic Syariah that are developed and embraced by Bimanese people [14]. For instance, "sabua nggahi labo rawi" means one word and deed. The term means honesty, not pride, helping each other, caring for others, and respecting each other.

Civic education is the right educational instrument to reinforce maja labo dahu (shame and fear) attitude towards students by the ways, including: 1) verbal reinforcement, 2) reinforcement by nudity, 3) habituation.

Verbal reinforcement of a Civic education teacher can describe the meaning of maja labo dahu philosophy (shame and fear) in everyday life. Verbal reinforcement (oral) is affected enough to shape the character of the student. As explained by Frymier \& Houser [15], the student empowerment depends on verbal and nonverbal instructions, carried out by the teacher because it is in direct contact with the student's feelings. Furthermore, the reinforcement of exemplary, such as teachers can show good attitudes and behaviours (honest, disciplined, polite and polite), so that students can imitate and they will be able to influence the formation of maja labo dahu attitude in students. Along with the opinions of Scheerens and Blömeke [16], that qualified teacher is a teacher, having cognitive (knowledge) and non-cognitive skills (beliefs, attitudes, etc.). Meanwhile, reinforcement of habituation is creating a pleasant condition for students by providing compassion, care for the same, family, and greetings and smiles.

The supporting factor of the reinforcement of maja labo dahu (shame and fear) attitude towards students of MTsN I Bima city is:

1) Teacher Competence, i.e., teachers, having pedagogical and intellectual skills. As explained by Sholikhin [17], a good teacher is a teacher, who can be imitated and provide stimulus to his/her students. Furthermore, Osguhorpe [18] argues that the exemplary, committed by a teacher in teaching, is easier to follow in shaping the character of learners than teaching.

2) The facility is a supporting medium in the teaching and learning process and it is even very influential to shape the character of students. Along with the statement from Irfan Azis as a teacher of extracurricular activity that the existence of adequate facility is influential enough to develop the talents and interests of students that will shape the character of students such as CCTV.

3) Habituation (School culture) has a significant influence in the formation of maja labo dahu (shame and fear) attitude towards students. It means the habit of being honest, polite, disciplined, religious etc. Habit is an important part of the neo-Aristotelian approach as ethics and morality understand it as the process of developing virtue [19].

While the inhibition factor of strengthening maja labo dahu (shame and fear) attitude towards students in MTsN I Bima city is:

1) the value of local wisdom maja labo dahu (shame and fear) has not included into the material of the learning curriculum of Pancasila and Civic education. So, it will be difficult for teachers to develop local wisdom values in learning. As explained by Nuro'in as a Pancasila and civic education teacher in MTsN I Bima city, references, which are related to bimanese culture, are still minimal, so that many teachers do not develop maja labo dahu (shame and fear) values in character education, based on local wisdom.

2) A large school environment will tend to be difficult for picket teachers to monitor student activities. As stated by Nurhasanah as a student representative of MTsN I Bima City, the small number of teachers will be overwhelmed to monitor students that are in a large school environment.

3) CCTV is still limited to certain places. This is one of the obstacle factors of the reinforcement of maja labo dahu (shame and fear) attitude or character education towards students because it is not balanced with the breadth of the school area and many buildings that stand, so that students are easy to do undisciplined.

4) a less supportive family and community environment for the growth of student morality. Because character education and value education, obtained by students in school, are not relevant to family education and community conditions.

The form of practicing the values of Pancasila in MTsN I Bima city is: first principle, the value of Belief in the one and only God contains religious meaning and morality. Rahmat Saleh A. [20] explains religious values and morality as the foundation of Islamic teachings that must be possessed by the community, i.e.:

a) The basic values of ubudiyah include reading the Qur'an, memorizing hadiths and praying in congregation.

b) The basic values of ahlakul karimah / morality following the Sunnah of the Prophet (peace and blessings of Allah be upon him) include manners, honesty, discipline, and tolerance.

c) The value of discipline, Islam as a religion that governs all human life associations, including high discipline as a form of respect for time, responsibility, and hard work.

The second principle, humanity has a meaning of tolerance, respect to human rights, help, respect to differences, and maintains harmony because it is bound by civilized human values. Civilization in the life of society is formed because of the similar value of human beings, who want to build a life together without neglecting differences. In connection with Latif's opinion [21] that the second principle of Pancasila reflects awareness in the Indonesian nation that has a universal sense of humanity.

Third, the unity of Indonesia contains nationalist meanings and love of the country includes raising the red and while flag, wearing batik, loving culture and awareness of preserving nature. Akuupa, U. M \& Korner, G [22] explained that efforts to maintain unity in diversity at the community level are commemorating the Freedom Day by involving all participating communities. The fourth principle, populism means democracy, includes political participation in the election of the head of the student council, school health scouting, deliberation and consensus. And fifth principle, social justice contains the meaning of equality of rights and obligations as citizens that are all students are viewed equally regardless of social classification. In fact, the principle of justice is to uphold 
justice, based on the values of democracy and human rights. Conceptually, justice has four meanings. 1) justice can be interpreted as unbalanced unhinged. 2) justice is equality without discrimination. 3) Justice can be interpreted as giving personal rights in accordance with the obligations that have been done. 4) god-derived and intrinsic justice [23].

\section{Conclusion}

The social dynamics of Bimanese society at this time is far from the philosophy of maja labo dahu (shame and fear) that upholds the values of religion, humanity, tolerance, deliberation and consensus, and the value of justice (Pancasila). Since regarding the emergence of various kinds of horizontal conflicts between villages, fighting between students, corruption, motorcycle theft, rape, early marriage, drug and alcohol addiction. A number of problems indicate a shift in the cultural values of Bimanese people that is synonymous with religion, tolerance, friendship, kinship, hard work, honesty, discipline and responsibility. Therefore, the importance of the reinforcement of maja labo dahu (shame and fear) attitude is in practicing the value of Pancasila through the learning of Pancasila and Civic education in MTsN I Bima City in order to make students able to understand maja labo dahu philosophy (shame and fear) as cultural value, the basis of character education and give awareness to students to practice the values of Pancasila.

\section{References}

1. Kerr, D. (1999). Citizenship education: An international comparison. National foundation for Educational ResearchNFER. Available at: https://edudoc.educa.ch/static/xd/2003/59.pdf

2. Budimansyah, D (2010). Tantangan globalisasi terhadap pembinaan wawasan kebangsaan dan cinta tanah air di sekolah. Jurnal Penelitian Pendidikan, 11 (1), 7-13.

3. Ubaedillah, A., Rozak, A. (2015). Pendidikan Kewarnegaraan (Civic education) Pancasila, demokrasi, HAM, dan masyarakat madani. Jakarta: Prenada Media group.

4. Latief, A., Nadir, M., Pangalila, T., Lonto, A. L., Suyanto T., Warsono, M. (2018). Revitalizing the value of Pancasila in the development of the character of Indonesia citizens. Advances in social science, education and humanities research. Proceedings of the 1 st internasional conference on social sciences (ICSS 2018). doi: http://doi.org/10.2991/icss-18.2018.191

5. Iskarim, M. (2016). Dekadensi Moral di Kalangan Pelajar (Revitalisasi Strategi PAI dalam Menumbuhkan Moralitas Generasi Bangsa). Jurnal edukasia islamika, 1 (1). Available at: https://media.neliti.com/media/publications/69187-ID-dekadensi-moraldi-kalangan-pelajar-revi.pdf

6. Morawska, A., Filus, A., Haslam, D., Sanders, M. R. (2017). The International Parenting Survey: Rationale, Development, and Potential Applications. Comprehensive Child and Adolescent Nursing, 42 (1), 40-53. doi: http://doi.org/10.1080/ 24694193.2017.1384082

7. Oberle, E., Schonert-Reichl, K. A., Guhn, M., Zumbo, B. D., Hertzman, C. (2014). The role of supportive adults in promoting positive development in middle childhood: A population-based study. Canadian Journal of School Psychology, 29 (4), 296-316. doi: http://doi.org/10.1177/0829573514540116

8. Nawawi, H. (2000). Buku: Metode Penelitian Bidang Sosial. Yogyakarta: UGM Press.

9. Moleong, L (2017). Metodelogi penelitian kualitatif. Bandung: Remaja Rosdakarya, 424.

10. Wihardjo, R. S. D., Pitri, F., Hasanah, U., Nurani, Y., Ramadhan, S. (2020). Social Behavior of Social Prone Women Related to Norms, Ethics and Environmental Aesthetics in Prumpung. International Journal of Psychosocial Rehabilitation, 24 (8), 10952-10963.

11. Sofyan, H., Anggereini, E., Muazzomi, N. (2020). Developing e-module local wisdom based for learning at kindergarten. Elementary Education Online, 19 (4), 2074-2085. doi: http://doi.org/10.17051/ilkonline.2020.763331

12. Mungmacho, R. (2012). Knowledge and local wisdom: community treasure. Internasional Journal of Humanities and Social Science, 2 (13), 174-181. Available at: http://www.ijhssnet.com/journals/Vol_2_No_13_July_2012/18.pdf

13. Alfian, M. (2013). Potensi kearifan lokal dalam pembentukan jati diri dan karakter bangsa. Prosiding the 5 tahun ICSSIS; "Ethnicity and globalization, 424-435.

14. Hasnun, A. (2020). Mengenal Orang Bima dan Kebudayaannya. Penerbit: BILDUNG Banguntapal Bantul Yogyakarta.

15. Frymier, B. A., Houser, L. M. (2009). The Role of Student Characteristics and Teacher Behaviors in Students' Learner Empowerment. Journal Communication Education, 58 (1), 35-53. doi: http://doi.org/10.1080/03634520802237383

16. Scheerens, J., Blömeke, S. (2016). Integrating teacher education effectiveness research into educational effectiveness models. Journal Educational Research Review, 18, 70-87. doi: http://doi.org/10.1016/j.edurev.2016.03.002

17. Sholikhin, M. (2010). Ritual Dan Tradisi. Penerbit. Yogyakarta: IKAPI.

18. Osguthorpe, R. D. (2008). On the reasons we want teachers of good disposition and moral character. Journal of Teacher Education, 59 (4), 288-299. doi: http://doi.org/10.1177/0022487108321377

19. Kerr, J. (2011). Habituation: a method for cultivating starting points in the ethical life. Journal of Philosophy of Education, 45 (4), 643-655. doi: http://doi.org/10.1111/j.1467-9752.2011.00826.x

20. Aulia, R. L (2016). Implementasi nilai religius dalam pendidikan karakter bagi peserta didik di sekolah dasar juara Yogyakarta. Spektrum Analisis Kebijakan Pendidikan, 5 (3), 314-323.

21. Latif, Y (2011). Negara paripurna: Historisitas, Rasionalitas, dan aktualitas Pancasila. Jakarta: PT. Gramadia pustaka Utama.

22. Akuupa, U. M., Korner, G (2013). From 'One Namibia, one Nation' towards 'Unity in Diversity'? Shifting representations of culture and nationhood in Namibian Independence Day celebrations, 1990-2010. Anthropology southern Africa, 36 (3), 34 46. doi: http://doi.org/10.1080/23323256.2013.11500041

23. Samidi, R., Suharno, S. (2018). Implementasi nilai keadilan sosial melalui pendidikan perspektif TGKH Zainuddin Abdul Majid. Jurnal Kajian Agama, Sosial dan Budaya, 3 (2), 374-384. doi: http://doi.org/10.25217/jf.v3i2.314

Received date 29.12.2020 Accepted date 25.01.2021

Published date 30.01.2021

Bambang Irawan, Pancasila and Citizenship Education, Faculty of Social Science, Univesitas Negeri Yogyakarta, Setiabudi, Jakarta, Indonesia, 12920

E-mail: bambangirawan.2018@student.uny.ac.id

Eny Kusdarini, Pancasila and Citizenship Education, Faculty of Social Science, Univesitas Negeri Yogyakarta, Setiabudi, Jakarta, Indonesia, 12920 